\title{
The Transformation of the US Strategy in the Middle East: Retreat after 2011
}

\author{
Qifeng Fang ${ }^{1 *}$, Xiaocheng $\mathrm{Lu}^{2}$ \\ ${ }^{1}$ School of Government, College of Social Science, University of Birmingham \\ ${ }^{2}$ Birmingham Business School, College of Social Science, University of Birmingham \\ *Email:QXF805@student.bham.ac.uk
}

\begin{abstract}
Since the Cold War, the United States believes in less militarized foreign policy, anchored more on diplomacy, aid, and democracy-building efforts than military intervention. Nonetheless, this belief was largely short-lived after Saddam Hussein invaded Kuwait and the September 9/11 attacks on the United States. The United States welcomed hard power, or rather power projection, to those it believed to threaten international peace and stability and homeland security. By 2011, the United States found itself trapped in a region where it can neither transform nor leave due to its interest, allies, and adversaries. The public's cost-benefit analysis established that the US's military intervention in the Middle East was long overdue and resulted in extensive military expenditure. While the United States cannot ignore notable challenges that beset the Middle East region, especially the humanitarian crisis in Syria, Yemen, Egypt, Israel's vulnerability, and oil interest, Washington has taken a strategic approach. This paper argues for the retreating role of the US in the Middle East since 2011, with troops withdrawing from conflict areas and sustaining a non-intervention approach. Nonetheless, the United States continues to take a keen interest in five critical factors without resolving power projection: nuclear armament, ensuring the oil trade, fighting terrorism, protecting Israel, and promoting democratization.
\end{abstract}

Keywords: Arab Springs, Geopolitics, Hegemony Middle East, Isolationist, Power Projection, United States.

\section{INTRODUCTION}

The American voters reflected lethargy over the apparently endless wars in the Middle East, the cost of supporting troops in hostile territories, and concerns over the loss of lives in the last three presidential elections. The pacifist candidates towards the Middle East intervention won. Recent studies found that 50 per cent of Americans believe Washington should "let middle Easterners resolve their conflicts," and 25 per cent stated that the United States should leave the region altogether [11]. While such undertones have prevailed in the contemporary views regarding the United States, it is crucial to examine the United States' foreign policy keenly to understand Washington's views on the Middle East. Firstly, the Middle Eastern region has been of vital interest for United States foreign policy dating back to the Red Line Agreement (1924) and the Anglo-American Petroleum Agreement (1944), with critical interests being petroleum control and economic involvement. Following the Iraq invasion in Kuwait leading to the 2003 Iraq War and the September 9/11 attacks on the
Twin Towers, the United States' foreign policy on the Middle East took a new turn. It was an opportunity for Washington to establish a "new world order." While the United States' objectives, which include promoting democracy, defeating terrorist groups, and safeguarding human rights, were genuine, new realities hit by the end of 2011. Washington realized their stay in the Middle East was overdue. The paper is divided into three main sections; the first provides a brief perspective on the United States' role in the Middle East before 2011, the second part makes a case for retreat. Here, two main issues present: the significant changes within the foreign policy landscape and the Middle East dynamics. The paper ends with a counterargument on the US retreating and a conclusion.

\section{THE US'S PRE-2011 ROLE IN THE MIDDLE EAST}

The discussion on American foreign policy, especially in the Middle Eastern region, is a confusing elixir of normative proposals and questionable empirical 
assertions. Nonetheless, to understand the United States' policies, it is essential to consider the American commitment as a global leader after the Second World War. Scholars must appreciate how other nations view the United States' foreign policy and consider the actual American military presence [11]. The discussion on the "how US role in the Middle East has been retreating since 2011" takes three primary dimensions. Firstly, the postWorld War II theorist argues that the United States became a hegemony, exerting power dominance and leadership worldwide [2] [29]. Washington has taken a fundamental interest in Middle East affairs based on unique perspectives; (a) it is a crucial determinant of the United States national's security; (b) the United States has constantly asserted its need to restore global peace and stability; and (c) economic interests.

Several theoretical arguments support US foreign policy and involvement in the Middle East and, equally, the retreat. Gause [11] argues that the United States policy attitudes and action towards the Middle East are anchored on realism- the general pursuit of national interest disguised as moral concerns. Here, the realists propose that the international system is an anarchist (lacking central authority). Thus, actors are concerned with their security, pursue their interests and struggle for power [7] [28]. While there have been legitimate reasons, including Kuwait's sovereignty (after Saddam's invasion) and national security in the nuclear world, Washington's "bigger picture" has always been oil, Israel, and anticommunism [15]. By the end of World War II, the United States' response to various fiscal and safety issues within the Middle East grew significantly. Based on the realist model, the United States' interest within the region includes ensuring strategic oil access in the Gulf, supporting, and safeguarding Israel sovereignty, and defending friendly regimes, that is, those supporting the United States ideals [15]. There have been vital security interests, including resisting Islamic movement groups that threaten the United States' national security, such as Hamas, Al-Qaeda, and the Islamic State of Iraq and Syria (ISIS).

\section{THE CASE FOR RETREAT: NEW DYNAMICS FOR FOREIGN POLICY: THE FOREIGN AFFAIRS LANDSCAPE HAS SIGNIFICANTLY CHANGED SINCE 2011, INSTIGATING CHANGE IN THE UNITED STATES' ROLE}

By 2011 significant changes occurred in the United States and globally, introducing new dynamics to Washington's foreign policy approaches, especially those of the Middle East. Firstly, the Soviet Union that long effected the American foreign policy was no more [10]. Here, the Cold War commentaries on foreign policy argue that part of the US's occupation in the Middle East was to prevent Soviet Union influence within the region
[32]. For example, the United States' attempts to influence the Iranian election (1979) were anchored on fears of pro-Russian establishment, which could negatively influence the United States' power stature. The subsequent decline of the Soviet Union meant that the United States lived in a different world from when the Middle East was central to East-West rivalry. Nonetheless, while the decline of the Soviet Union meant new dawn for Middle East relations, notable events around 2011 marked a significant departure for the United States.

Firstly, the United States' foreign policy in the Middle East have radically changed. Here, scholars identify two perspectives influencing the US foreign policy in the Middle East: hard and soft powers. On the hard powers side, following the 9/11 attack, the United States declared war on terrorist groups and countries that, from Washington's point of view, harboured the terrorist groups [9] [22]. The Middle Eastern region mainly, Iraq and Afghanistan, were considered critical points for antiAmerican factions, including the Al-Qaeda and Taliban [6] [20]. Subsequently the 9/11 key mastermind Osama bin Laden was killed on 2 May 2011 also shows the United States hard powers in Middle East. In soft powers, according to Jenkins [16], Officials in Washington noted that within 18-24 months of the United States invasion in Afghanistan, the al Qaeda were degraded to mere "propaganda arm" and had been strategically defeated. On 13 Jun. 2002, the United States supported the election of Hamid Karzai as the first democratically elected candidate to lead the nation. Roughly ten years since declaring war on Middle Eastern countries harbouring terrorism, and showed it's hard and soft power, a lot of policy change had achieved by the United States.

Notably, President Obama declared his intention to pivot Washington's foreign policy efforts from the Middle East to Asia. In November 2011, approximately three years into his term, President Barrack Obama stated that

"The tide of war is receding. Now, even as we remove our last troops from Iraq, we are beginning to bring our troops home from Afghanistan, where we've begun a transition to Afghan security and leadership" [33]

Following President Obama's remarks, the administration chose to let the Status of Forces Agreement with Iraq lapse, sending the US forces stationed in the nation home. Since 2011, there have been restraint undertones in the United States foreign policy majority postulating that the US should depart from the Middle East. However, some argue that Middle Eastern countries are relatively stable and no longer a threat to the United States' peace and stability [34]. The restraint camps propose that we should no longer waste resources on overseas commitments. There is no longer much value (as it was after the September 9/11 attacks) to secure geographically strategic points in the Middle East since 
the United States security does not depend on it. The United States' challenge and interest have changed since 2011 like Painter and Baohui make two arguments regarding the United States retreating from the Middle East; (a) Washington no longer depends on the Middle East for oil stability, and (b) China and North Korea presents new challenges [5] [24]. The change of US dependency on Middle Eastern energy due to fracking technology has influenced policy changes. The United States has decided to 'pivot" its interest on China, an emerging hegemony challenger. Also, there have been calls within the United States to increase expenditure on military assets.

While the United States is inevitably present in different parts of the world since 2011, the administrations have shown commitment to scaling back responsibilities and obligations abroad. President Obama's addresses on reducing and subsequently withdrawing troops from Iraq marked a new foreign policy-isolationism for starters. While President Obama is not considered an "isolationist," according to many scholars, he laid the blueprint for future American policy anchored on focusing on the United States economy and "people" [13] [21] [30]. The isolationist doctrine entails policy to isolate a country from affairs of other nations by declining to intervene in international affairs, agreements, and attempts to make the country self-reliant [17] [19]. The isolationist hypothesis supports a country's regard to its interest and minimal efforts to exert external pressure on non-issue [34]. With President Donald Trump's election, the United States welcomed the isolationist reality, and the administration committed itself to remove troops around the world. One of the key commitments under President Trump's plan was the withdrawal of troops from the region that he described as full of "sand and death," reasserting his predecessors to the retreating role.

Several documented incidents demonstrated the United States' retreat in the Middle East from a foreign policy perspective. Besides the United States' declarations of the withdrawal of troops from Iraq and Afghanistan (discussed earlier), two critical recent events demonstrate America's accelerated retreat in the Middle East. In September 2019, Iranian missile truck the oil facilities of Saudi's Aramco. Since Saudi Arabia is a close ally to Washington, people expected the United States to act or stage an international foreign policy response [25]. Instead, the United States did nothing leading to speculation of the future of the United States as a key strategic ally to some Middle East countries. Subsequently, President Trump announced a pull-out of American troops from Syria. Notable foreign policy commentaries The New York Times argue that the United States abandoned its Kurdish allies and left the people to the mercy of the Turkish military offensive by leaving Syria [26].

\section{THE MIDDLE EAST IS NOW A COMPLEX REGION}

The Middle East has been shaken by unrest in recent years, through increased violence and instability caused by the Arab springs uprising and the spread of Islamistextremist terrorist organizations with strong anti-Western ideology. For the United States, most countries in the Middle East present the fundamental challenge and necessitate a cost-benefit analysis [14] [31]. When the United States departed from Iraq in 2011, there was little for the massive military investment or earlier allegation that Saddam has weapons of mass destruction. Despite the United States invasion of Iraq, the region is of massive interest to global security. The rise of Islamic State militants complicated the United States' efforts within the region, and, according to Washington, there was no longer a critical strategic vantage point [7]. With instability within the Iraqi region, President Obama's administration considered retreat.

Syria is another nation of interest introducing complexities for the United States administration. Afghanistan and Pakistan are equally volatile regions with critical concerns about whether the United States has significantly prepared the government to deal with Taliban and Al Qaeda resurgence within the region [29]. The President Biden administration has indicted its commitment towards withdrawing troops by the end of the year 2021. These efforts are primarily influenced by significant military expenditure, public calls for costbenefit analysis, and, more importantly, challenges within the region. Indeed, the United States cannot be embroiled in conflict to infinity.

Although nothing to do with the United States' intervention, some countries within the Middle East still have had a fair share of volatility. The rise of Arab springs in 2011, which saw the ouster of President Hosni Mubarak in 2011, marked a significant change in geopolitics within the region [4] [18]. On the one side, the people involved in Arab springs seem to uphold the American thesis for fundamental freedoms, democracy, and removal of the authoritarian regime. However, on the other side, after the US-NATO involvement in Libya, there have been criticisms of the United States' efforts to restore stability in the region. Interestingly, during the Egypt uprising, the United States was significantly a bystander choosing not to intervene. A similar narrative prevails in the Libya situation whereby the United States and NATO airstrikes made the ouster of Moammar Gadhafi [12]. At the same time, Libya descended into anarchy, including the attacks on Benghazi. The subsequent closure of the United States embassy in the country signified its decision to step aside from the conflict, non-involvement.

Further, countries in the Middle East have gained considerable bargaining power, some emerging as a 
critical influence in the region and others gaining strategic partners. Iran is a classic case of a country that the United States should reckon with. Iran is commanding key influences within contemporary geopolitics, especially the Syria and Israel conflict [27]. Washington has chosen to take a strategic approach when dealing with such nations like Iran. The United States and other powers are negotiating with Iran on its nuclear program, which is an extraordinary circumstance compared to how the United States dealt with the Iraq threat. Interestingly, President Hassan Rouhani supports the Assad government and Hamas and Hezbollah. With lessons from Iraq, Afghanistan, and Libya involvement, it is arguable that the United States prefers order over chaos. While the United State is still a hegemony over the Middle Eastern countries.

\section{COUNTER ARGUMENT}

The argument that the US's involvement in the Middle East has been diminishing. since 2011 is subject to broad scholarly arguments. Byman and Moller [8] argue that the United States continues to posit several critical interests in the Middle East; (a) fighting terrorism and Islamic militants; (b) preventing nuclear proliferation; (c) maintaining Israel's security; and (d) promoting democratization. The evidence of United States involvement is widespread, and more importantly, these efforts counter the retreating thesis. Although the Obama administration resisted large-scale military involvement in Iraq, in 2014, it prevents Islamic State advances in Iraq through airstrikes on the militants. In 2019, the Trump administration conducted air raids that killed Iraq general Qasem Soleimani, who was considered a threat to the United States [3]. Despite commitments to withdraw, the United States continued to provide humanitarian aid to conflict-affected areas and displaced Iraqis. Regarding safeguarding the United States oil interest within the Middle East region, a lot has changed. Today, the United States does not depend on the region's oil [1]. However, most United States allies, and partners (Japan, South Korea, Philippine, Singapore, and Taiwan) depend on the Middle East and thus need to safeguard the region. Equally important, the United States has not abandoned efforts to secure Israel, which significantly draws Washington to Middle East politics and relations. Israel is a United States partner united with a common dedication to democracy, economic success, and regional security [8].

Therefore, the retreating hypothesis is misplaced with the United States remaining steadfast in supporting Israel against Iran, Syria, and Palestine. The main counterargument on United States' retreating role in the Middle East is that the US is not only interested in defeating terrorism within the region or reasserting global dominance. Instead, there is considerable legitimate interest, including pushing back China's predatory trade practices. Stephen H. Gotowicki and his colleague Bernard Reich argue that the United States zealousness in safeguarding the Middle Eastern region was partly influenced by the Soviet threat, which diminished by the end of the 20th century [8] [35]. With China seeking to exert global dominance, the United States is unlikely to stand by and watch [36].

\section{CONCLUSION}

The argument that the US's involvement in the Middle East has been diminishing. since 2011 is subject to broad scholarly arguments. Byman and Moller [8] argue that the United States continues to posit several critical interests in the Middle East; (a) fighting terrorism and Islamic militants; (b) preventing nuclear proliferation; (c) maintaining Israel's security; and (d) promoting democratization. The evidence of United States involvement is widespread, and more importantly, these efforts counter the retreating thesis. Although the Obama administration resisted large-scale military involvement in Iraq, in 2014, it prevents Islamic State advances in Iraq through airstrikes on the militants. In 2019, the Trump administration conducted air raids that killed Iraq general Qasem Soleimani, who was considered a threat to the United States [3]. Despite commitments to withdraw, the United States continued to provide humanitarian aid to conflict-affected areas and displaced Iraqis. Regarding safeguarding the United States oil interest within the Middle East region, a lot has changed. Today, the United States does not depend on the region's oil [1]. However, most United States allies, and partners (Japan, South Korea, Philippine, Singapore, and Taiwan) depend on the Middle East and thus need to safeguard the region. Equally important, the United States has not abandoned efforts to secure Israel, which significantly draws Washington to Middle East politics and relations. Israel is a United States partner united with a common dedication to democracy, economic success, and regional security [8].

Therefore, the retreating hypothesis is misplaced with the United States remaining steadfast in supporting Israel against Iran, Syria, and Palestine. The main counterargument on United States' retreating role in the Middle East is that the US is not only interested in defeating terrorism within the region or reasserting global dominance. Instead, there is considerable legitimate interest, including pushing back China's predatory trade practices. Stephen H. Gotowicki and his colleague Bernard Reich argue that the United States' zealousness in safeguarding the Middle Eastern region was partly influenced by the Soviet threat, which diminished by the end of the 20th century [8] [35]. With China seeking to exert global dominance, the United States is unlikely to stand by and watch [36]. 


\section{REFERENCES}

[1] Al Sarhan, AS (2017). United States foreign policy and the Middle East. Open Journal of Political Science, [online] 07(04), pp.454-472. Available at: https://eis.hu.edu.jo/deanshipfiles/pub1135110198 7.pdf [Accessed 3 Jun. 2021].

[2] Aniskiewicz, R., Artz, L. and Murphy, B.O. (2001). Cultural hegemony in the United States. Contemporary Sociology, [online] 30(6), p.594. Available at: https://www.researchgate.net/publication/2696477 74_Cultural_Hegemony_in_the_United_States [Accessed 3 Jun. 2021].

[3] Arraf, J. and Hassan, F. (2021). US airstrike kills top ISIS leader in Iraq. The New York Times. [online] 29 Jan. Available at: https://www.nytimes.com/2021/01/29/world/middl eeast/us-airstrike-kills-top-isis-leader-in-iraq.html [Accessed 3 Jun. 2021].

[4] Atlas, P.M. (2012). US foreign policy and the Arab spring: Balancing values and interests. Digest of Middle East Studies, 21(2), pp.353-385.

[5] Baohui, Z. (2012). Chinese foreign policy in transition: Trends and implications. Journal of Current Chinese Affairs, [online] 39(2), pp.39-68. Available at: https://journals.sagepub.com/doi/pdf/10.1177/1868 10261003900202 [Accessed 3 Jun. 2021].

[6] Boyle, M.J. (2008). The war on terror in American grand strategy. International Affairs, 84(2), pp.191209.

[7] Brown, S. (2016). Higher realism: A new foreign policy for the United States. 1st ed. Abingdon, UK; New York, NY: Routledge, pp.2-34.

[8] Byman, D. and Moller, S. (2016). The United States and the Middle East: Interests, risks, and costs. Oxford University Press, [online] 14(3), pp.1-17. Available at: http://tobinproject.org/sites/tobinproject.org/files/a ssets/Byman\%20\%26\%20Moller\%20$\% 20$ The $\% 20$ United $\% 20$ States $\% 20$ and $\% 20$ the $\% 20$ Middle\%20East_0.pdf [Accessed 3 Jun. 2021].

[9] Cole, J. (2009). Pakistan and Afghanistan: Beyond the Taliban. Political Science Quarterly, [online] 124(2), pp.221-249. Available at: https://www.jstor.org/stable/pdf/25655653.pdf?cas a_token=bZH0W_ohy9QAAAAA:dAJQ31pKLfelH1p_hC11cj_bKFM6H3NbLPrqOE Df4AOUR69P96bKTPuGhdCsNyw_6thfjYILIYQ VT2tZiXygKcy70wwvmZ_6j3VXqKVq3BE6pUF Pvd-pw [Accessed 3 Jun. 2021].
[10] David, S.R. (2006). American foreign policy towards the Middle East: A necessary change? Israel Affairs, 12(4), pp.614-641.

[11] Gause, F.G. (2019). Should we stay, or should we go? The United States and the Middle East. Survival, [online] 61(5), pp.7-24. Available at: https://www.tandfonline.com/doi/epub/10.1080/00 396338.2019.1662114?needAccess=true [Accessed 3 Jun. 2021].

[12] Hashemi, N. (2020). The Arab spring, US foreign policy, and the question of, and the question of democracy in the Middle East. Denver Journal of International Law and Policy, [online] 41(1), pp.33-38. Available at: https://digitalcommons.du.edu/cgi/viewcontent.cgi ?article $=1108 \&$ context $=$ djilp $\quad$ Accessed 3 Jun. 2021].

[13] Hemmer, C. (2011). Continuity and change in the Obama administration's national security strategy. Comparative Strategy, 30(3), pp.268-277.

[14] Hu, D., Cooper, A., Desai, N., Guo, S., Shi, S. and Banks, D. (2019). Cost-Benefit analysis of discretionary wars. Statistics and Public Policy, [online] 6(1), pp.98-106. Available at: https://amstat.tandfonline.com/doi/pdf/10.1080/23 30443X.2019.1688740 [Accessed 3 Jun. 2021].

[15] Hudson, M. (1996). To play the hegemon: Fifty years of US policy toward the Middle East. Middle East Journal, [online] 50(3), pp.329-343. Available at: https://www.jstor.org/stable/4328954 [Accessed 3 Jun. 2021].

[16] Jenkins, B.M. (2012). Al Qaeda in its third decade: Irreversible decline or imminent victory? Santa Monica, CA: RAND Corporation, pp.1-18.

[17] Johnstone, A. (2011). Isolationism and internationalism in American foreign relations. Journal of Transatlantic Studies, 9(1), pp.7-20.

[18] Keiswetter, A. (2012). The Arab Spring: Implications for US policy and interests. [online] Middle East Institute. Available at: https://www.mei.edu/publications/arab-springimplications-us-policy-and-interests [Accessed 3 Jun. 2021].

[19] Kertzer, JD (2013). Making sense of isolationism: Foreign policy mood as a multilevel phenomenon. The Journal of Politics, [online] 75(1), pp.225-240. Available at: https://www.jstor.org/stable/pdf/10.1017/S002238 1612000989.pdf?casa_token=Vpn7tqgyMbcAAA AA:0rLHCf2T74e9u6w6U4lLwSKMGfimOog0Q o8t1- 
Jk5Y_t_S_4gnm4DnXQvqlm0T1U1j_zlTpMvCH O3d0kPePLQouane402xkI9myjJJkIxOoOY2mU9W3IA [Accessed 3 Jun. 2021].

[20] McIntosh, C. (2014). Ending the war with Al Qaeda. Orbis, [online] 58(1), pp.104-118. Available at: https://www.academia.edu/download/53828617/En ding_the_War_Orbis_2013_CEC.pdf [Accessed 3 Jun. 2021].

[21] Metzger, G. (2011). Is Obama an isolationist? Thinking clearly about a slogan \& a slur. Commonweal magazine. [online] 29 Jul. Available at: https://www.commonwealmagazine.org/obamaisolationist [Accessed 1 Jun. 2021].

[22] Morris, C. (2019). To what extent has US foreign policy contributed to an increase in religiousinspired terrorism since 1945? Journal of Global Faultlines, [online] 6(2), pp.186-203. Available at: https://www.jstor.org/stable/pdf/10.13169/jglobfau 1.6.2.0186.pdf [Accessed 3 Jun. 2021].

[23] O'Donnell, M. (2007). Review: US foreign policy in the Middle East. Media International Australia incorporating Culture and Policy, 122(1), pp.212213.

[24] Painter, D.S. (2012). Oil and the American century. Journal of American History, [online] 99(1), pp.2439. Available at: https://academic.oup.com/jah/articlepdf/99/1/24/2540046/jas073.pdf?casa_token=Sxz MRJrQ6toAAAAA:edmdsWP0WCNfTgEXibEAT RBeupka3ZI1FyZ5CMMbbDXUxkR0ogNe2B1xC KAPfBT3WOWxWcbszsFa3YQ [Accessed 3 Jun. 2021].

[25] Pamuk, H. (2019). Exclusive: US probe of Saudi oil attack shows it came from North - Report. Reuters. [online] 20 Dec. Available at: https://www.reuters.com/article/us-saudi-aramcoattacks-iran-exclusive-idUSKBN1YN299 [Accessed 3 Jun. 2021].

[26] Hubbard, B., Savage, C., Schmitt, E. and Kingsley, P., 2019. Abandoned by U.S. in Syria, Kurds Find New Ally in American Foe (Published 2019). [online] Nytimes.com. Available at: <https://www.nytimes.com/2019/10/13/world/mid dleeast/syria-turkey-invasion-isis.html> [Accessed 3 June 2021].

[27] Pillar, P.R. (2013). The role of villain: Iran and US foreign policy. Political Science Quarterly, [online] 128(2), pp.211-231. Available at: https://www.jstor.org/stable/pdf/23563304.pdf?cas a_token=BzU0Xh0ZFnkAAAAA:R5JVhyr_dhN4 P571fuzpjizjzsciJ7hIFdpEleaXrQcBdx6QIk9NDD 4-
PSRDfqK8omSz8rFBnl54qjHVJ0LlRvD881qA111 GjZumYoT8199BgBPiePCoxg [Accessed 3 Jun. 2021].

[28] Rø, J.G. (2018). Mechanistic realism and US foreign policy: A new framework for analysis. 1st ed. SL: Routledge, pp.6-24.

[29] Siracusa, J.M. (2012). Andrew Baker. Constructing a post-war order: The rise of US hegemony and the origins of the Cold War. The American Historical Review, [online] 117(4), pp.1253-1254. Available at: https://academic.oup.com/ahr/articlepdf/117/4/1253/23676164/zah1253a.pdf?casa_toke n=stF36nf5VFwAAAAA:AWYjaSdzustEgGXdac S6wIa4RFUYkNNZp9K9klYuzW8JavFbyUmHjw5rc31JXmRDrwwsZk-SWOHBF0 [Accessed 3 Jun. 2021].

[30] Skidmore, D. (2011). The Obama presidency and US foreign policy: Where's the multilateralism? International Studies Perspectives, [online] 13(1), pp.43-64. Available at: https://www.researchgate.net/profile/David_Skidm ore3/publication/230538723_The_Obama_Preside ncy_and_US_Foreign_Policy_Where's_the_Multil ateralism/links/5ab17d5d0f7e9b4897c39e0a/TheObama-Presidency-and-US-Foreign-PolicyWheres-the-Multilateralism.pdf [Accessed 3 Jun. 2021].

[31] Stiglitz, J. and Bilmes, L.J. (2008). The three trillion dollar war: The true cost of the Iraq conflict. New York, NY; London, UK: W. W. Norton \& Company, p.16.

[32] Takeyh, R. (2000). The United States' Cold War priorities and the Middle East, 1945-53. In: The Origins of the Eisenhower doctrine the US, Britain, and Nasser's Egypt, 1953-57. London, UK: Palgrave Macmillan, pp.1-4.

[33] The White House Office of the Press Secretary (2011). Remarks by the President on the way forward in Afghanistan. [online] The White House. Available at: https://obamawhitehouse.archives.gov/the-pressoffice/2011/06/22/remarks-president-way-forwardafghanistan [Accessed 3 Jun. 2021].

[34] Urbatsch, R. (2010). Isolationism and domestic politics. Journal of Conflict Resolution, [online] 54(3), pp.471-492. Available at: https://citeseerx.ist.psu.edu/viewdoc/download?doi $=10.1 .1 .880 .1664 \&$ rep=rep1\&type=pdf [Accessed 3 Jun. 2021].

[35] Al Sarhan, A., 2017. United States Foreign Policy and the Middle East. Open Journal of Political Science, 07(04), pp.454-472. 
[36] Reich, B. and Gotowicki, S., 1994. The United States and the Soviet Union in the Middle East. In: D. Howard Goldberg, S. Page, P. Marantz, and S. Gotowicki, ed., The Decline of the Soviet Union and the Transformation of the Middle East, 1st ed. Boulder: Westview Press.

[37] Wintour, P., 2020. US v China: is this the start of a new cold war?. [online] the Guardian. Available at: <https://www.theguardian.com/world/2020/jun/22/ us-v-china-is-this-the-start-of-a-new-cold-war > [Accessed 3 June 2021]. 